\title{
A Rare Case of Chordoma and Craniopharyngioma Treated by an Endoscopic Endonasal, Transtubercular Transclival Approach
}

\author{
Endoskopik Endonazal, Transtüberküler Transklival Yaklaşımla Tedavi \\ Edilen Nadir Bir Kordoma ve Kraniyofarenjiyoma Olgusu
}

Maurizio IACOANGELI ${ }^{1}$, Alessandro Dİ RIENZO ${ }^{1}$, Roberto COLASANTI ${ }^{1}$, Marina SCARPELLI ${ }^{2}$, Maurizio GLADI ${ }^{1}$, Lorenzo ALVARO ${ }^{1}$, Niccolò NOCCHI ${ }^{1}$, Massimo SCERRATI $^{1}$

1 Università Politecnica delle Marche, Department of Neurosurgery, Ancona, Italy

2Università Politecnica delle Marche, Department of Pathological Anatomy, Ancona, Italy

Corresponding Author: Maurizio IACOANGELI / E-mail: neurotra@tiscali.it

\begin{abstract}
Co-occurrence of different brain tumors is rarely observed, being more frequent in patients affected by genetic syndromes like phacomatoses. Different histological types of intracranial lesions may present at different times in the clinical history of the patient or, more rarely, they may occurr at the same moment. In these last cases, particularly for tumors located in adjacent areas of the brain, diagnostic difficulties may arise. Moreover, even when the correct diagnosis is established, treatment strategy becomes complex and a single staged approach could be ineffective in obtaining successful tumor removal. We report a case of simultaneous sellar-suprasellar craniopharyngioma and intradural clival chordoma, successfully treated by a single staged, extended, fully endoscopic endonasal approach, which required no following adjuvant therapy. We also discuss the potential etiopathogenesis of the two lesions, reviewing the literature.
\end{abstract}

KEYWORDS: Vestigial tumor, Intradural, Chordoma, Endoscopic approach, Craniopharyngioma

öz

Farklı beyin tümörlerinin birlikte görülmesi nadirdir ve fakomatozlar gibi genetik sendromları olan hastalarda daha sıktır. Farklı intrakraniyal lezyon histolojik tipleri aynı hastanın klinik öyküsünde farklı zamanlarda ortaya çıkabilir veya daha nadiren aynı anda görülebilirler. İkinci durumda özellikle beynin komşu bölgelerinde bulunan tümörler açısından tanısal problemler oluşabilir. Ancak doğru tanı konduğu zaman bile tedavi stratejisi karmaşıktır ve tek evreli bir yaklaşım başarılı tümör çıkarma açısından etkisiz olabilir. Adjuvan tedavi gerekmeyecek şekilde tek evreli genişletilmiş tam endoskopik endonazal yaklaşımla başarıyla tedavi edilen bir eş zamanlı sellar-suprasellar kraniyofarenjiyoma ve intradural klival kordoma olgusu sunuyoruz. Literatürü gözden geçirerek bu iki lezyonun olası etiyopatogenezini tartışmaktayız.

ANAHTAR SÖZCÜKLER: Vestijial tümör, İntradural, Kordoma, Endoskopik yaklaşım, Kraniyofarenjiyoma

\section{INTRODUCTION}

Chordomas are quite rare slow-growing lesions with local malignancy, generally located in the axial bony structures, rarely occurring in intradural location (2). The origin of craniopharyngiomas is more controversial. They are generally thought to derive from squamous epithelial cells rests in Rathke's cleft or to develop from metaplastic foci of residual adenohypophyseal squamous epithelium (1). We describe a case of co-occurrence of a sellar-suprasellar craniopharyngioma and a clival intradural chordoma, successfully treated via an extended, endoscopic endonasal approach.

\section{CASE REPORT}

A 24-year-old man was admitted to our Department because of a 4-weeks history of headache, visual deficits and transient diplopia. Computed tomography (CT) revealed a hypodense mass extending from the sellar region to the clivus, with intrasellar calcifications. No bone erosion was observed (Figure $1 \mathrm{~A}-\mathrm{C}$ ). Magnetic resonance imaging (MRI) evidenced a huge intradural mass involving the sellar-suprasellar region, displacing upward the chiasm, descending along the clivus, dislocating posteriorly the upper brainstem and the basilar artery. The lesion appeared hypointense on $\mathrm{T} 1$ and hyperintense on $\mathrm{T} 2$ sequences. The clival component of the lesion showed a less homogeneous enhancement after gadolinium administration when compared to the sellar component (Figure 1D-F). Endocrinological evaluation revealed panhypopituitarism and diabetes insipidus.

The patient underwent an extended endoscopic endonasal transtubercular-transclival approach, aimed at controlling the whole lesion by multiple working angles. After exposing 
the dural layer from the sellar floor to the clivus, the dura was opened. The upper component of the lesion, partly solid and partly cystic, was easily removed by suction/dissection technique. The aspect of the clival portion was different. It appeared grayish, gelatinous, firmly adherent to the adjacent structures and the removal was gross-total, exposing the basilar trunk and the brainstem. A watertight closure was performed using a subdural inlay graft of collagen matrix, an overlaying fascia lata graft over the clivus and a nasoseptal mucosal flap over the sellar floor. The retropharyngeal mucosa was finally re-approximated and closed by full thickness stitches. Nasal packing to reduce risks of graft migration was

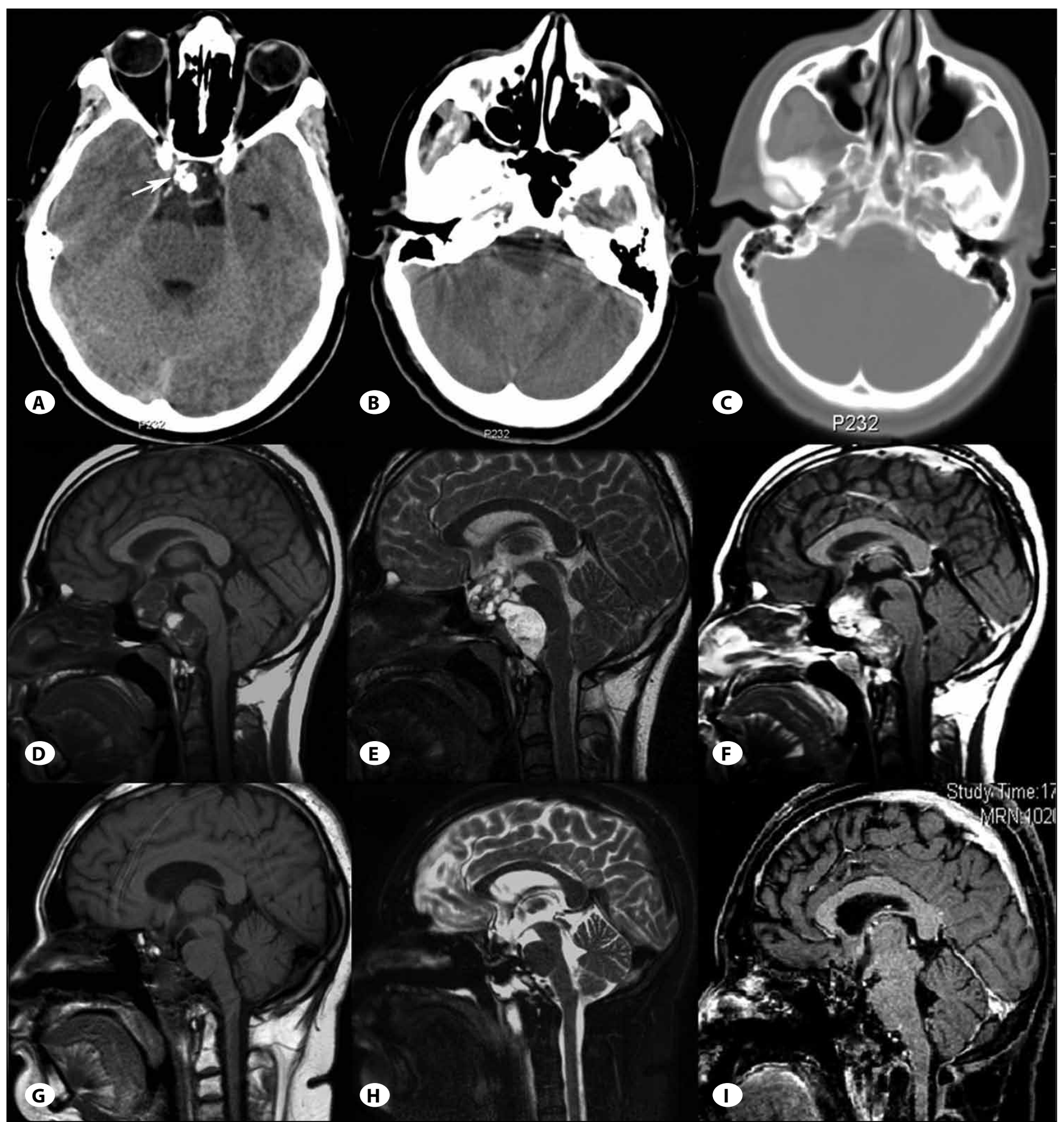

Figure 1: Admission CT revealing a hypodense sellar mass with calcifications (white arrow) (A, B) and without bone erosion (C). T1 (D), T2 (E), postgadolinium-T1 (F) sagittal MRI confirming an intradural, bilobate suprasellar-sellar-retroclival mass, with brainstem compression. Two-years follow-up sagittal T1 (G), T2 (H) and postgadolinium-T1 (I) MRI demonstrated brainstem re-expansion without tumor recurrence. 
performed by a dual chambered silicone catheter, inflated under endoscopic control.

Postoperative course was uneventful and patient's visual and endocrine deficits rapidly improved.

Histopathologic examination disclosed the presence of two different tumors. The sellar-suprasellar lesion showed confluent laminated masses of keratin with extensive calcification (wet keratin) surrounded by an exuberant gliotic reaction with Rosenthal fibers. Very small fragments of squamous epithelium interpreted as infiltrating tongues of craniopharyngioma were also identified (Figure 2A,B). The retroclival lesion was an intradural chordoma, composed of large cells arranged in cohesive sheets and cords separated by scant myxoid and basophilic stroma. The cytoplasm was abundant and vacuolated, giving the cells their characteristic "physaliphorous" aspect. The nuclei were bland and mitotic activity was not apparent. The tumor showed intense and diffuse staining for cytokeratin and S100 protein (Figure 2C,D). No relationship between the two lesions was found at histologic examination.
MRI, performed 3-6 and 12 months after surgery, then once a year, confirmed a gross-total removal of the lesions with no recurrences at 2 years follow-up (Figure 1G-I).

\section{DISCUSSION}

The oncological interest of this case is represented by the cooccurrence of two midline cerebral tumors both developing from vestigial remnants but histologically unrelated.

The origin of craniopharyngiomas remains controversial. They are generally thought to derive from squamous epithelial cells rests in Rathke's cleft. Another hypothesis suggests a development from metaplastic foci of residual adenohypophyseal squamous epithelium. Anyway the theory of a dual origin does not question their vestigial origin (1). Although their most common location is the suprasellar region, they can rarely extend along the skull base in the posterior fossa (3). Thereby, despite a radiological differentiation between craniopharyngiomas and chordomas is possible, a lesion extending from the suprasellar region to the retroclival area may create diagnostic difficulties.
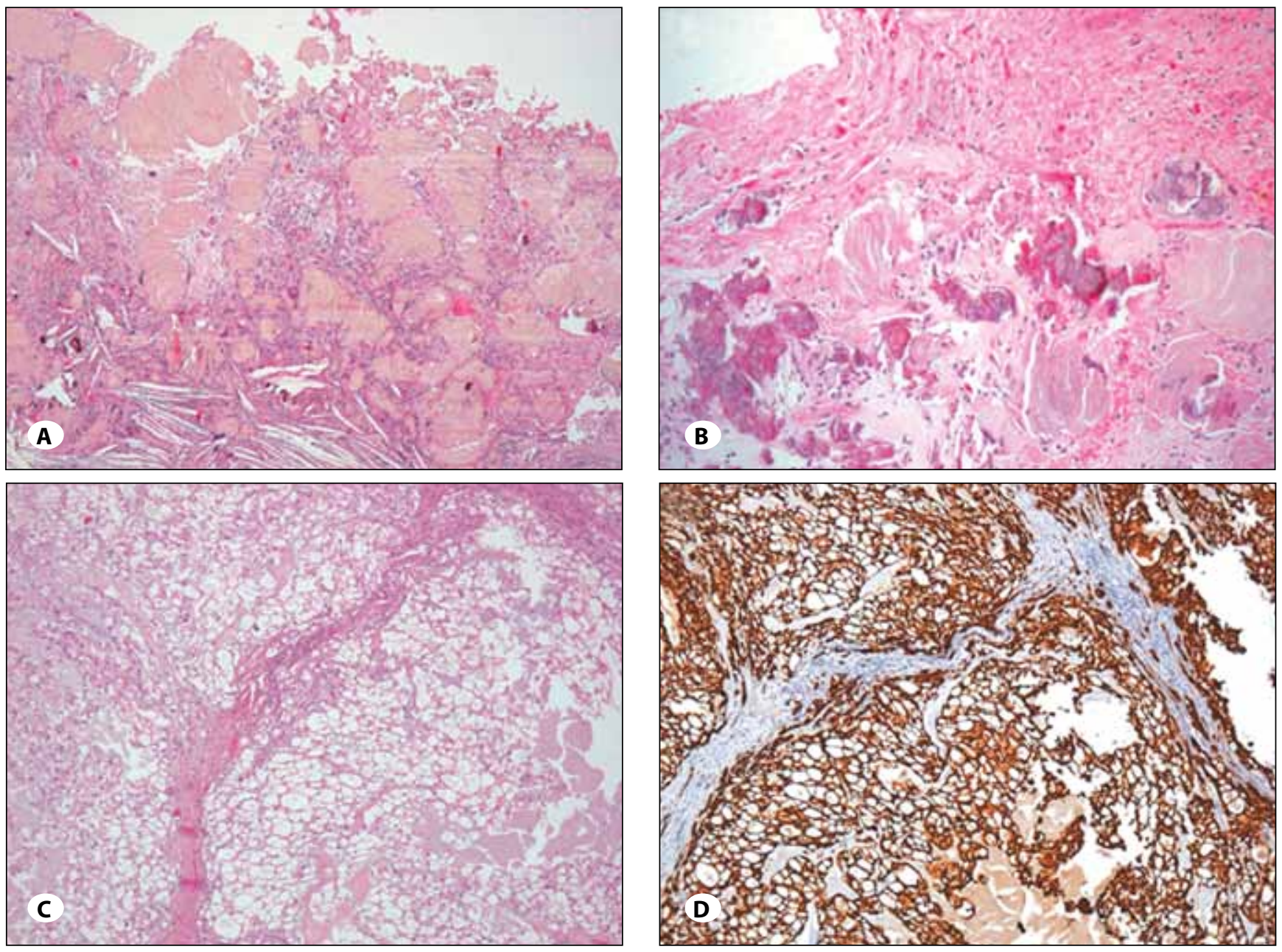

Figure 2: Photomicrographs of surgical specimens. Craniopharyngioma: confluent laminated masses of "wet keratin" (A). Gliotic reaction with Rosenthal fibers surrounding masses of keratin (B). Chordoma composed of large physaliphorous cells (C). Cytokeratin AE1-AE3 staining of the chordoma (D). 
Chordomas are said to derive from notochordal remnants, which may get intrapped intracranially along the sigmoid curve that the notochord describes through the clivus, reaching the pharyngeal surface and the dorsum sellae. They generally present a slow, extradural growth causing extensive lytic destruction of the involved bone. Intracranial intradural chordomas are very rare, with only few cases reported in literature to date. Especially when located in the prepontine region, their prognosis is better than that of chordomas invading the surrounding bone, where complete surgical resection can be extremely difficult (2). The main differential diagnoses for chordomas are metastatic mucinous carcinomas, chordoid meningiomas and chondrosarcomas. In particular chordoid meningioma, an uncommon variant of meningioma with a propensity for aggressive behaviour, may show significant morphologic overlap but usually does not have a prominent cytokeratin and $\mathrm{S} 100$ reactivity. Other immunohistochemical markers, such as D2-40, brachyury and GFAP can also be applied for differential diagnosis (5). The leading differential diagnosis for intradural chordomas is ecchordosis physaliphora (EP), commonly considered to be a rare, benign, usually asymptomatic, congenital malformation derived from notochordal tissue that is typically located inside the prepontine cistern. The two lesions have identical microscopic, immunohistochemical and ultrastructural characteristics and although histopathological observation of hypocellularity, sparse pleomorphism and absence of mitoses, typical of EP, may be helpful, there are not definitive diagnostic criteria to differentiate chordomas from EP. Both show similar signal intensity characteristics on MRI but, unlike chordomas, EP demonstrates lack of enhancement after gadolinium injection. It has been hypothesized that EPs may give rise to intradural chordomas, but this is still a matter of debate (2).

Except for cases observed after radiotherapy or in phacomatoses, multiple primary intracranial tumors of different histologic types are rare. Several mechanisms have been proposed but there is no conclusive evidence. Based on the observation of adjacent tumor localization, it was thought that one tumor may act as an irritative stimulus for the development of the other. Some author suggests a common carcinogenic agent; others believe that tumor combinations occur simply by chance (4).

At present, the "gold standard" therapy for chordomas and craniopharyngiomas consists of radical surgical removal. To the best of our knowledge, only one case of association of a craniopharyngioma with a chordoma has been previously reported (1).
In recent years, endoscopic endonasal approaches have gained a large interest for the treatment of midline skull base tumors, because of the minimal invasiveness of the approach, the potential to obtain adequate exposure of large lesions by the "extended" procedures, without sacrifice of safety and the effectiveness in terms of removal (3). In the case reported, the endoscopic endonasal approach was selected to operate along one surgical corridor allowing multiple working angles for removing what we considered a single lesion. The success of the procedure was made possible by the wholly intradural location of the tumor. By this technique we were able to optimize lesions removal minimizing manipulation and risks of injury to vital neurovascular structures. An accurate, multilayer, watertight reconstruction, enforced by the creation of a nasoseptal mucosal flap and by hermetic closure of the pharyngeal mucosa, enabled us to isolate definitely the cranial cavity from the sinonasal tract, avoiding postoperative cerebrospinal fluid leakage, which is the most feared complication in these approaches. Actually, an accurate reconstruction in skull base surgery is strategic to accelerate the scarring process in cases needing adjuvant radiotherapy.

Concluding, we feel that the good results obtained by a single staged surgery in the reported case seem to support the effectiveness, minimal invasiveness and relative safety of the endoscopic approaches in the treatment of midline skull base lesions.

\section{REFERENCES}

1. Belza J: Double midline intracranial tumors of vestigial origin: Contiguous intrasellar chordoma and suprasellar craniopharyngioma. Case report. J Neurosurg 25:199-204, 1966

2. Bhat DI, Yasha M, Rojin A, Sampath S, Shankar SK: Intradural clival chordoma: A rare pathological entity. J Neurooncol 96: 287-290, 2010

3. Kawamata T, Kubo O, Kamikawa S, Hori T: Ectopic clival craniopharyngioma. Acta Neurochir (Wien) 144:1221-1224, 2002

4. Lee EJ, Chang $\mathrm{CH}$, Wang LC, Hung YC, Chen HH: Two primary brain tumors, meningioma and glioblastoma multiforme, in opposite hemispheres of the same patient. J Clin Neurosci 9:589-591, 2002

5. Sangoi AR, Dulai MS, Beck AH, Brat DJ, Vogel H: Distinguishing chordoid meningiomas from their histologic mimics: An immunohistochemical evaluation. Am J Surg Pathol 33: 669-681, 2009 